\title{
Globodera rostochiensis (Woll.) Behrens (Tylenchida, Heteroderidae), the only potato cyst nematode species found in Finland
}

\author{
JARI HEIKKILÄ and KARI TIILIKKALA
}

\begin{abstract}
HeikKILÄ, J. \& TilikKala, K. 1992. Globodera rostochiensis (Woll.) Behrens (Tylenchida, Heteroderidae), the only potato cyst nematode species found in Finland. Agric. Sci. Finl. 1: 519- 525. (Univ. Helsinki, Dept. Zoology, SF-00100 Helsinki, Agric. Res. Centre of Finland, Inst. Pl. Protect., SF-31600 Jokioinen, Finland.)

About 10000 soil samples, 519 thereof infected with potato cyst nematode (PCN), were studied during 1984-1988. Cysts from infected samples were tested by isoelectric focusing to identify PCN species. All the infected samples were also tested with H1-resistant (Saturna) and susceptible (Bintje) potato cultivars to separate resistance breaking populations. Cysts from the roots of Saturna were tested by two-dimensional electrophoresis.

The potato seed production area in Finland was found to be free of PCN of any kind. In other parts of Finland all tested samples revealed $G$. rostochiensis banding pattern, but no G. pallida was found. Except for the most common pathotype Ro1-Ro4, we only found Ro2.
\end{abstract}

Key words: potato cyst nematode, PCN, Globodera rostochiensis, Globodera pallida, isoelectric focusing, two-dimensional electrophoresis

\section{Introduction}

In Finland, potatoes are grown commercially on about 41000 hectares. The cultivated area extends from the southern coast $\left(60^{\circ} 00^{\prime} \mathrm{N}\right)$ up to the north $\left(69^{\circ} 00^{\prime} \mathrm{N}\right)$. The growing season for potatoes extends from mid-May to the end of August in southern Finland. In the north the growing season is more than one month shorter (MUKULA and RANTANEN 1987).

Potato cyst nematode (PCN), Globodera rostochiensis, was found in Finland for the first time in 1946 (VAPPULA 1954), and the first noticeable damage on commercial potato farms appeared in the early 1970s (SARAKOSKI 1976a). Since the beginning of the 1970 s, PCN has been the most harmful pest of potatoes in Finland.

MAgnusson (1987) and TillikKaLA (1987, 1991) have studied the biological and physical factors affecting the success of $G$. rostochiensis. In Finland, the whole life cycle of $G$. rostochiensis requires over 600 day degrees above $4.4^{\circ} \mathrm{C}$. This means that $G$. rostochiensis is well adapted to the low soil temperatures and is able to develop in the whole potato growing area up to the polar circle. The northernmost observation in Finland is a few kilometers north of the Polar circle (SARAKOSKI 1976b). Considering that Globodera pallida needs 
fewer day degrees to reproduce than does $G$. rostochiensis (FOOT 1978, MUGNIERY 1978, FrANCO 1979), one would expect $G$. pallida to be an even more successful species in Finland. If $G$. pallida females develop faster and produce eggs sooner than $G$. rostochiensis at lower temperatures (WEBLEY and JONES 1981), this could lead to gradual replacement of G. rostochiensis. On the other hand, at $24^{\circ} \mathrm{C} \mathrm{G}$. rostochiensis produces more juveniles than does G. pallida (WEBLEY and JONES 1981).

Both species are common in Central Europe, and have been found in Sweden (OLSSON 1985 a, 1985 b), Norway (ÖYDVIN 1973, 1978), Iceland (SIGGEIRSSON and VAN RIEL 1975), and in Denmark (JAKOBSEN and HANSEN 1983). In Finland, MAGNUSSON (1979) pointed out that although some of her populations, tested with test plants in the greenhouse, did not fit into any pathotype group, no observations of $G$. pallida had been made till 1979.

Reliable identification of species is a key factor when control programs are evaluated. These testing procedures should also be applicable to routine plant protection practice. Testing methods for identification of species and pathotyping of potato cyst nematodes were studied to develop a system for the analysis of populations with low numbers of larvae in the cysts.

According to several authors (FLEMING and MARX 1982, 1983, OHMS and HeINICKE 1983, FoX and ATKINSON 1984, MARX and FLeming 1985, FLEMING 1987), isoelectric focusing of general proteins is a useful method to identify potato cyst nematode species. Isoelectric focusing and staining of general proteins have been used successfully also to determine other plant parasitic species e.g. with Meloidogyne spp., (DALMASSO and BERGE 1978, LAwSON et al. 1984), and with animal parasites e.g. several Cestoda species (DIXON and ARAI 1985, 1987). We concentrated on isoelectric focusing and on identification of species directly from rude soil samples. Some problems related to the identification of pathotype are also discussed.

The aims of this study were 1) to investigate the probable disribution of Globodera pallida in Fin- land, and 2) the establishment of $\mathrm{H} 1$ resistance breaking pathotypes.

\section{Material and methods}

Soil samples of about one litre per hectare (ca. 0.2 dl subsamples collected randomly from the area) were taken during routine farm inspection by the Plant Quarantine Office, or were sent by farmers in July-August during 1984-88. The total number of one litre samples was about 10000 . The sampling area covered the whole country from southernmost Finland to north of the polar circle. The sampling intensity differed somewhat from area to area, being more intense in western and southern Finland (Fig.1).

Samples were washed either in a Fenwick can, 250 grams dry soil per wash, or in a Schuiling centrifuge, $1 \mathrm{dl}$ dry soil per wash. Cysts were picked manually from the filter paper. Cysts were stored dry for several months in a refrigerator before identification of species. The rest of the samples were stored at about $5^{\circ} \mathrm{C}$, until used in plant tests.

Isoelectric focusing (FLEMING and MARX 1983), with slight modifications, was used in identification of species as follows. About 20 cysts per sample were soaked in $1 \%$ glycine for at least 24 hours in $1.5 \mathrm{ml}$ microcentrifuge tubes. After soaking, cysts were crushed, homogenates fuged and 20 microliter samples were pipetted onto pieces of filter paper on the $1 \mathrm{~mm}$ thick polyacrylamide gel plates, $\mathrm{pH}$ range 3.5-9.5 (LKB, Bromma, Sweden). Separation of the proteins was performed for 70 minutes at $4^{\circ} \mathrm{C}$. Gels were stained for general proteins with Goomassie Brilliant Blue.

The rest of the soil was used for testing the samples with H1-resistant (Saturna) and susceptible (Bintje) potato cultivars. Pots of $2 \mathrm{dl}$, submerged in peat and filled with sample soil, were planted with both cultivars. Four replicates at least were used. The pots were kept in greenhouses at $18^{\circ} \mathrm{C}$ for eight weeks. Cysts formed on the roots of Saturna were picked and stored in a refrigerator for 


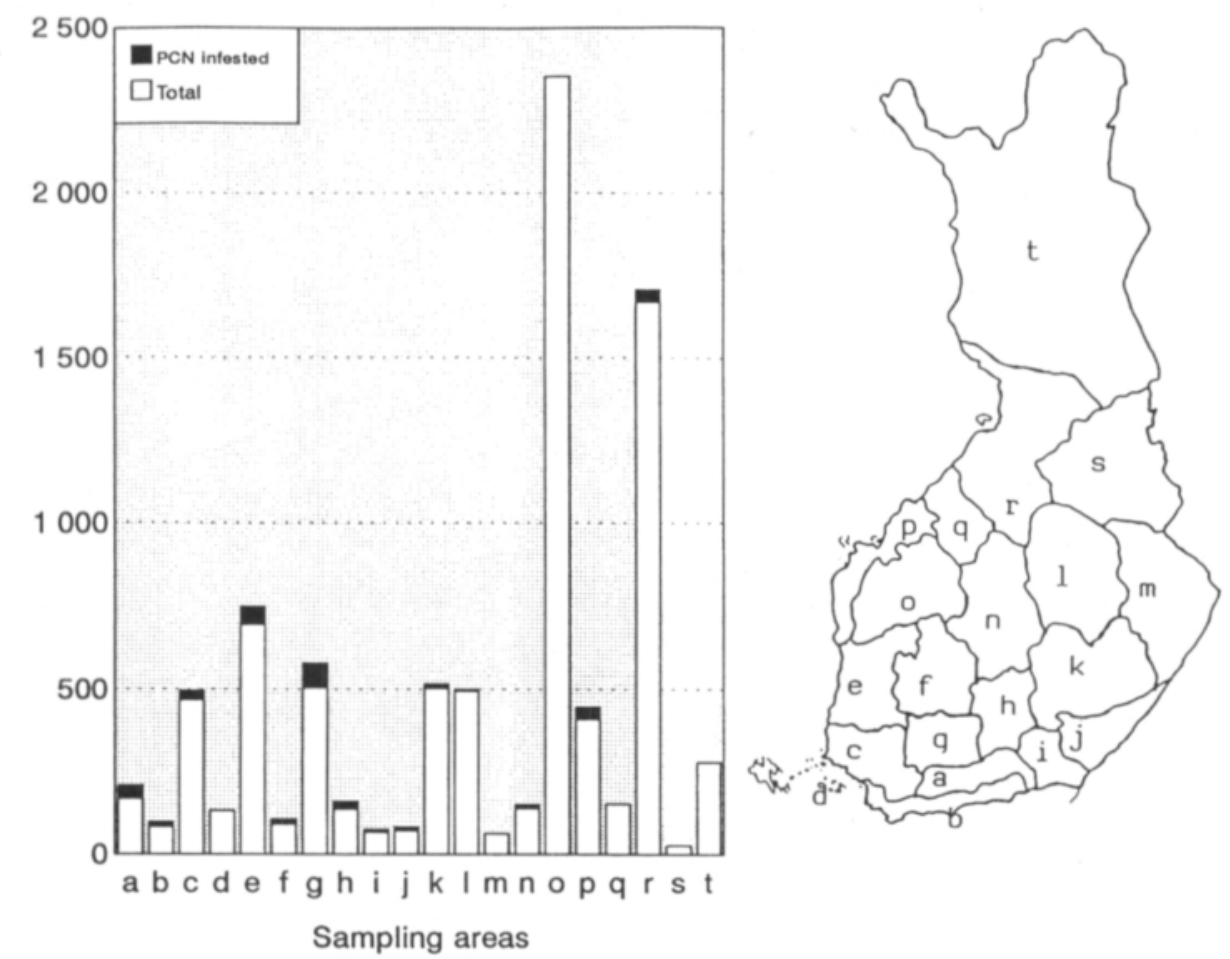

Fig. 1. Soil samples and sampling areas. Letters (a to $\mathrm{t}$ ) indicate the sampling areas and white bars the total number of soil samples per area. Black bars present the numbers of PCN infested samples.

pathotype testing. Larvae from field samples were counted to get an estimate of initial densities for plant tests. Approximately ten cysts per sample, when available, were crushed and larvae were counted under a microscope without diluting.

Because isoelectric focusing separates species, but is not sensitive enough to identify pathotypes, 2-D electrophoresis (OHMS and HEINICKE 1985) was used for pathotype identification of cysts developed on the roots of the H1-resistant cultivar Saturna.

\section{Results}

All samples tested by isoelectric focusing revealed G. rostochiensis banding patterns. No G. pallida bands were seen.
Plant tests directly confirmed the results in all (519) but twelve samples tested with Bintje and Saturna. No cysts had developed on the roots of Saturna, except for twelve samples (Table 1). But, because the isoelectric banding pattern clearly showed them to be G. rostochiensis, we must be dealing with some other pathotypes of $G$. rostochiensis than Rol or Ro4. These "resistance breaking" populations were found in different localities and on areas of several Agricultural Advisory Centers, which means that they probably are independent of each other.

2D-electrophoresis revealed Rol or Ro2 pathotype banding patterns. In the gels it is impossible to separate these pathotypes from each other.

The small number of larvae in cysts extracted from soil samples from the fields where "resistance breaking" populations had been found (Table 1) 
Table 1. Average number of cysts and larvae per cyst from Saturna tests.

\begin{tabular}{lrrrrr}
\hline \multirow{2}{*}{ Sample } & \multicolumn{2}{c}{ Initial population } & & \multicolumn{2}{c}{ Saturna tests } \\
\cline { 2 - 3 } & $\begin{array}{r}\text { Cysts/ } \\
\text { 250 soil }\end{array}$ & $\begin{array}{r}\text { Larvae/ } \\
\text { cyst }\end{array}$ & $\begin{array}{r}\text { Cysts/ } \\
\text { plant }\end{array}$ & $\begin{array}{r}\text { Larvae/ } \\
\text { cyst }\end{array}$ \\
\hline 53 & 170 & 98 & 34 & 11 \\
112 & 286 & 38 & 35 & 40 \\
121 & 70 & 97 & 18 & 37 \\
135 & 19 & 50 & 3 & 5 \\
146 & 245 & 66 & 263 & 61 \\
204 & 29 & 54 & 3 & 33 \\
246 & 128 & 68 & 25 & 63 \\
258 & 280 & 87 & 51 & 82 \\
284 & 145 & 42 & 23 & 35 \\
322 & & & 26 & 19 \\
348 & 145 & 18 & 1 & 26 \\
460 & 75 & 75 & 48 & 23 \\
\hline
\end{tabular}

was a remarkable and interesting point And so was the small number of cysts per plant, and especially the even smaller number of larvae per cyst extracted from roots of Saturna in most "resistance breaking" samples compared to the soil samples (Table 1). The difference was statistically signific-ant (paired $\mathrm{t}$-test, $\mathrm{p}=0.0221$ ) between the mean number of larvae per cyst from soil samples and that from potato roots.

\section{Discussion}

The total number of clearly visible bands in isoelectric focusing of general proteins of $G$. rostochiensis and $G$. pallida is highly dependent on the quality of the sample and the sample preparation method used. However, there are a couple of species specific and diagnostic major bands which are useful in identification of the species. Moreover, these diagnostic bands are not particularly sensitive either to the quality of the sample or the way a sample has been prepared, although the position of these bands may vary according to the preparation method. Our results are comparable with FLEMING and MARX (1982, 1983), and MARX and FLEMING (1985) because of the same methodology.
Our finding that $G$. rostochiensis seems to be the only PCN species in Finland is somewhat surprising. The other species, G. pallida, exists in all neighbouring countries. Moreover, climatic and other environmental factors in Finland rather favor $G$. pallida at the expense of $G$. rostochiensis than prevent its existence. Our suggestion is simply that $G$. pallida has not yet invaded Finland.

The potato seed production area along the west coast of the Baltic sea seems to be free of PCN of any kind. Commercial farmers often have contracts which provide the farmers to use seed potato of high quality. This may help to control the PCN problem on those areas.

The census procedure is directed to commercial potato farms, and hence leaves small-scale household farming out of control. Uncontrolled exchange of seed and machinery leaves at least theoretical possibilities that these small household gardens could function as a reservoir for PCN and G. pallida as well.

Species can be identified by isoelectric focusing of general proteins. Our results indicate that $G$. rostochiensis is the only potato cyst nematode species in Finland, but the pathotype question needs more attention. Application of the two-dimensional electrophoresis in pathotype identification has been used successfully elsewhere, but in Finland there have been some difficulties. The sample quality must be good, which in our situation is difficult to achieve. The places where "strange" pathotypes were found are few, indicating recent infection. Moreover, the small number of cysts, and especially the small number of larvae per cyst limits the applicability of the system for routine use, and hence the information needed and the purpose must be properly defined.

When comparing for example the Dutch (BAKER 1987) and German (HEINICKE pers. comm.) traditions in the use of 2D-electrophoresis in PCN identification, there is one obvious difference in their level of operation. BAKKER (1987) clearly emphasizes the importance of exact determination of alleles and hence the genetic structure of PCN popu- 
lations. This, of course, preconceives optimalization of the procedure which, in turn, makes the whole system less applicable to routine work. In Germany the approach is different, more practically oriented. When certain spots are found in the 2Dgels, it automatically leads to the naming of certain pathotypes and to routine control procedures with resistant cultivars even though the exact pathotype and genetic background are unknown. In Finland the situation is easier because we have only one $\mathrm{PCN}$ species, and the number of populations where resistance breaking pathotypes have emerged is small. In this situation it is possible to handle all suspected cases individually by leaving them out of potato cultivation. This requires only the identification of abnormal cases which not necessarily require any complicated methodology. The problem which remains is the possibility some cysts to develop on the roots of resistant cultivars in the absence of resistance breaking pathotypes. In that case no or only few larvae will develop.

\section{References}

BAKKer, J. 1987. Protein variation in cyst nematodes. $\mathrm{PhD}$ thesis. Wageningen, Netherlands. 159 p.

Dalmasso, A. \& Berge, J.B. 1978. Molecular Polymorphism and Phylogenetic Relationship in some Meloidogyne spp.: Application to the taxonomy of Meloidogyne. J. Nematol. 10: 323-332.

Dixon, B.R. \& ARAl, H.P. 1985. Isoelectric focusing of soluble proteins in the characterization of three species of Hymenolepis (Cestoda). Can J. Zool. 63: 1720-1723.

- \& ARAI, H.P. 1987. An investigation of host influence on soluble protein banding profiles of Hymenolepis spp. (Cestoidea), using isoelectric focusing. Can. J. Zool. 65: 2471-2474.

FLEMING, C.C. 1987. The use of isoelectric focusing as a tool in the management of the potato cyst nematodes Globodera rostochiensis and Globodera pallida. 11th Intern. Congress of Plant Protection. Manilla, Philippines.

- \& MARKS, R.J. 1982. A method for the quantitative estimation of Globodera rostochiensis and Globodera pallida in mixed-species samples. Record of Agricultural Research 30: 67-70.

- \& MARKS, R.J. 1983. The identification of the potato cyst nematodes Globodera rostochiensis and G. pallida by isoelectric focusing of proteins on polyacrylamide gels. Ann. Appl. Biol. 103: 277-281.

Foot, M.A. 1978. Temperature responses of three potatocyst nematode populations from New Zealand. Nematologica 24: 421-427.

Fox, P.C. \& AtKinson, H.J. 1984. Isoelectric focusing of general proteins and specific enzymes from pathotypes of Globodera rostochiensis and G. pallida. Parasitology 88: 131-139.
Franco, J. 1979. Effect of temperature on hatching and multiplication of potato-cyst nematodes. Nematologica 25: 237-244.

JAKOBSEN, J. \& HANSEN, L.M. 1983. Identification of pathotypes of potato cyst nematodes (PCN) collected from infected private gardens. Plant diseases and pests in Denmark 1982. Lyngby.

Lawson, E.C., Carter, Jr, G.E. \& Lewis, S.A. 1984. Application of isoelectric focusing to the taxonomic identification of Meloidogyne spp.. J. Nematol. 16: 91-96.

Magnusson, M.L. 1979. The occurrence of different pathotypes of the potato cyst nematode, Globodera rostochiensis, in Finland. Ann. Agric. Fenn. 18: 154-159.

- 1987. Cultivated crops and climatic factors affecting the yellow potato cyst nematode, Globodera rostochiensis Behrens. Plant protection reports. SLU Uppsala. 36 p.

Marks, R.J. \& Fleming, C.C. 1985. The use of isoelectric focusing as a tool in the identification and management of potato cyst nematode populations. Eppo Bull. 15: 289-297.

Mugniery, D. 1978. Vitesse de developpement, en fonction de la temperature, de Globodera rostochiensis et G. pallida (Nematoda: Heteroderidae). Rev. Nematol. 1: 3-12.

Mukula, J. \& RANTANEN, O. 1987. Climatic risks to the yield and quality of field crops in Finland. Ann. Agric. Fenn. 26: 1-18.

OHмs, J.P. \& HeINICKE, D.H.K. 1983. Pathotypen des Kartoffelnematoden I. Schnellbestimmung der Arzugehörigkeit mittels Isoelektrofocussierung. Zeitschrift fur Pflanzenkrankheiten und Pflanzenschutz 90: 258-264.

OLsson, E. 1985a. Die Kartoffelnematoden Globodera rostochiensis (Woll.) Behrens und G. pallida (Stone) Behrens und ihre Pathotypen in Schweden. Potato Research 28: 497-506. 
- 1985b. Morphological-taxonomical studies and pathotype classification in potato cyst nematodes. Eppo Bull. 15: 281-283.

SARAKOSKI, M.L. 1976a. The distribution of the potato cyst nematode, Heterodera rostochiensis Wollenweber, in Finland. Ann. Agric. Fenn. 15: 111-115.

- 1976 b. Potato cyst nematode, Heterodera rostochiensis, discovered in Finnish Lapland. Nematologica 22: 223225.

Siggeirsson, E.I. \& VAN RIEL, H.R. 1975. Snikjupradormar i plöntum a Islandi. Rannsoknastofnunin Nedri As, Hveragerdi, Island. Skyrdsla 20. 32 p.

TIILIKKALA, K. 1987. Life cycle of the potato cyst nematode in Finland. Ann. Agric. Fenn. 26: 171-179.

- 1991. Effect of crop rotation on potato cyst nematode, Globodera rostochiensis, and potato yield. Eppo Bull. 21: 41-47.

VAPPULA, N.A. 1954. Nematod problem i Finland. Nord. Jordbr. forskn. 36: 323-325.

WeBley, D.P. \& Jones, F.G.W. 1981. Observations on Globodera pallida and Globodera rostochiensis on early potatoes. Pl. Path. 30: 217-224.
ÖYDVIN, J. 1973. The usefulness of some larval dimensions to distinquish Heterodera rostochiensis and $H$. pallida. Nematologica 19: 435-442.

- 1978. Studies on potato cyst-nematodes, Globodera spp. (Skarbilovich), and the use of plant resistance against $G$. rostochiensis (Woll.) in Norway. Växtskyddsrapporter. SLU Uppsala. 37 p.

Manuscript received May 1992

Jari Heikkilä

University of Helsinki

Department of Zoology

SF - 00100 Helsinki, Finland

Kari Tiilikkala

Agricultural Research Centre of Finland

Institute of Plant Protection

SF - 31600 Jokioinen, Finland 


\title{
SELOSTUS
}

\section{Globodera rostochiensis Woll. (Behrens) on toistaiseksi ainoa Suomesta löydetty peruna-ankeroislaji}

\author{
JARI HEIKKILÄ ja KARI TIILIKKALA
}

Helsingin yliopisto ja Maatalouden tutkimuskeskus

Peruna-ankeroislajeja on kaksi: Globodera rostochiensis ja G. pallida, joilla molemmilla on useita patotyyppejä măăriteltynä sen mukaan millä testiperunoilla ne lisääntyvăt. $G$. rostochiensis on yleisempi laji Euroopassa, joskin G. pallida on lisăäntynyt alueilla, joilla ankeroisenkestäviä perunalajikkeita on viljelty intensiivisesti. G. pallida -lajia esiintyy myös Tanskassa sekä Ruotsin ja Norjan etelăosissa. Ulkomaisten tutkimusten mukaan $G$. pallida on hyvin sopeutunut alhaisiin lämpötiloihin, joten se todennäköisesti myös menestyisi Suomessa paremmin ja olisi vahingollisempi kuin täällä jo oleva $G$. rostochiensis.

Tämän tutkimuksen tavoitteena oli selvittää: a) esiintyykö G. pallida Suomessa, b) onko Suomessa ankeroisenkestävillä perunalajikkeilla lisääntyviä $G$. rostochiensis -lajin patotyyppejä sekä c) miten bioteknisiä menetelmiä voidaan soveltaa peruna-ankeroisen lajimääritykseen. Tutkimus tehtiin pảăosin Maa- ja metsătalousministeriön varoin MTTK:n ja kasvinsuojeluviranomaisten yhteistyönă. Tutkitut maanäytteet saatiin Maatilahallituksen ankeroiskartoituksen yhteydessă sekă MTTK:n neuvontaan tulleista lähetyksistă. Näytteitä oli yhteensä noin 10000 ja niistä laji- ja patotyyppianalyyseihin sopivia elinvoimaisia ankeroisia oli 519 nåytteessä. Näytteitä saatiin kaikkien maatalouskeskusten alueilta, joskin pääosa oli otettu Etelä-, Keski- ja Pohjois-Pohjanmaalta.

Puhtaiden näytteiden suuri määrä osoitti, ettă peruna-ankeroinen ei ole vielă yleistynyt Pohjanmaalla eikä se uhkaa vălittömåsti siemenperunatuotannon jatkumista Siemenperunakeskuksen toimialueella. Kaikki löydetyt ankeroiset kuuluivat $G$. rostochiensis -lajiin, joten $G$. pallida ei ole toistaiseksi levinnyt lainkaan maahamme tai se on erittäin harvinainen. Valtaosa löydetyistä ankeroisita oli tyyppiä $\mathrm{Ro}_{1} / \mathrm{Ro}_{4}$, joka ei lisäänny ankeroisenkestävillä (andigena-resistenteillä) lajikkeilla. Kahdentoista năytteen ankeroiset lisăăntyivăt testikasvina kăytetyllä Saturnalla ja ne olivat alustavien tutkumusten mukaan tyyppiä Ro2. Tämän uuden ankeroistyypin, eli ns. "resistenssin murtajan" todettiin esiintyvän piilevänä jo useiden maatalouskeskusten alueella, joten ankeroisenkestävien perunalajikkeiden (Saturna, Stina, Hertha, Aminca, Prevalent, Provita) jatkuva viljely samalla paikalla voi johtaa resistenssin murtajien valikoitumiseen vallitsevaksi missä tahansa Suomessa.

Tämăn tutkimuksen mukaan lajin mäăritys voidaan tehdä luotettavasti ja nopeasti perunoiden juurista poimituista kystoista isoelektrisellä fokusoinnilla mikäli kystoissa on runsaasti toukkia. Lajin sisåisten erojen eli patotyyppien määritykseen tarvitaan testikasveja tai bioteknistä analytiikkaa, jonka soveltamisesta ja yhdenmukaisesta käytöstă ei ole păăsty sopimukseen Euroopan ja Välimeren maiden kasvinsuojelujärjestőssä (EPPO). Vuosittain löydettăvien uusien resistenssinmurtajien măărä jăănee toistaiseksi niin văhăiseksi, että patotyyppien määrittäminen on helpointa tehdä kansainvälisenäyhteistyönä jonkun Keski-Eurooppalaisen laboratorion kanssa. 